\title{
MLPH wt Allele
}

National Cancer Institute

\section{Source}

National Cancer Institute. MLPH wt Allele. NCI Thesaurus. Code C152012.

Human MLPH wild-type allele is located in the vicinity of $2 q 37.3$ and is approximately 70 $\mathrm{kb}$ in length. This allele, which encodes melanophilin protein, plays a role in melanosome transport. Mutation of the gene is associated with hypopigmentation in type 3 Griscelli syndrome. 